\title{
Assessing new strategies for TB diagnosis in low- and middle-income countries
}

\author{
Afranio Lineu Kritski ${ }^{*}$, Gisele Huf ${ }^{2}$, Martha Maria Oliveira ${ }^{3}$, S Bertie Squire ${ }^{4}$, Antonio Ruffino-Netto ${ }^{5}$ \\ From 5th Congress of the Brazilian Biotechnology Society (SBBIOTEC) \\ Florianópolis, Brazil. 10-14 November 2013
}

We will report the current situation of tuberculosis globally and in Brazil, the need for new strategies towards tuberculosis control, focusing on new diagnostic technologies. Critical comments are given on the state of the art regarding the evaluation of new health technologies, degree of scientific evidence needed, evaluation of clinical impact, cost-effectiveness of incorporation into the health system and the social impact.

Currently, the given pragmatic approach indicates that it is not appropriate to conduct an investigation on the incorporation of new technologies only in a "purely experimental" manner in clinical research centers. Research and practice clinical processes become intertwined and the main outcomes to be considered are the patient's health and actions creating a more effective health system in which the new technology will be incorporated. In this new scenario, it is essential that the academic biomedical areas reformulate their undergraduate curricula to include courses that address the development of new technologies, including the assessment of clinical impact, and economic and social incorporation of these new technologies into the current health system that will influence the future practice of their graduate students. In parallel, only through collaborative activities between academics, health service providers (public or private), producers of raw materials, laboratories and representatives of civil society will it be possible to conduct such studies under routine conditions in demonstration areas to enable an analysis appropriate to the relevance of the incorporation of new technologies in the country.

\footnotetext{
Authors' details

${ }^{1}$ Federal University of Rio de Janeiro, Rio de Janeiro, Brazil. ${ }^{2}$ ENSP-Fiocruz, Rio de Janeiro, Brazil. ${ }^{3}$ Rede TB, Rio de Janeiro, Brazil. ${ }^{4}$ Liverpool School Public of
}

Health, Liverpool, UK. ${ }^{5}$ Faculdade de Medicina USP- Ribeirao Preto, São Paulo, Brazil.

Published: 1 October 2014

\section{References}

1. World Health Organization: Global Tuberculosis Control: surveillance, planning, financing. Geneva: World Health Organization; 2010.

2. Stop TB Partnership and World Health Organization. Global Plan to Stop TB 2006-2015. Geneva, World Health Organization; 2006 [http://www. stoptb.org/assets/documents/global/plan/GlobalPlanFinal.pdf], (WHO/HTM/ STB/2006.35).

3. Marais BJ, Raviglione M, Donald PR, Harries AD, Kritski AL, Graham SM, El-Sadr W, Harrington M, Mwaba PO, Churchyard G, Kauffman SHE, Whitty CJM, Atun R, Zumla A: Scale-up of services and research priorities for TB diagnosis, management and control: Call to action. Lancet 2010, 375(9732):2179-2191.

4. Huf $G$, Kritski A: Evaluation of the clinical utility of new diagnostic tests for tuberculosis: the role of pragmatic clinical trials. J Bras Pneumol 2012, 38(2):237-245.

5. Thorpe KE, Zwarenstein M, Oxman AD, Treweek S, Furberg CD, Altman DG, Tunis S, Bergel E, Harvey I, Magid DJ, Chalkidou K: A pragmatic-explanatory continuum indicator summary (PRECIS): a tool to help trial designers. J Clin Epidemiol 2009, 62(5):464-75.

6. Wei X, Walley JD, Liang X, Liu F, Zhang X, Li R: Adapting a generic tuberculosis control operational guideline and scaling it up in China: a qualitative case study. BMC Public Health 2008, 8:260.

7. Mann G, Squire SB, Bissell K, Eliseev P, Du Toit E, Hesseling A, Nicol M, Detjen A, Kritski A: Beyond accuracy: creating a comprehensive evidence base for tuberculosis diagnostic tools. Int J Tuberc Lung Dis 2010, 14(12):1518-1524.

\section{doi:10.1186/1753-6561-8-S4-012}

Cite this article as: Kritski et al:: Assessing new strategies for TB diagnosis in low- and middle-income countries. BMC Proceedings 2014 8(Suppl 4):012.

${ }^{1}$ Federal University of Rio de Janeiro, Rio de Janeiro, Brazil

Full list of author information is available at the end of the article 